\title{
GLUTATHIONE AND ANTIOXIDANT ENZYMES INTHE HEPATOPANCREAS OF CRAYFISH PROCAMBARUS CLARKII (GIRARD, 1852) OF LAKE TRASIMENO (ITALY)
}

\author{
A. C. ELIA (1)*, A. J. M DÖRR (1), C. MASTRANGELO (1), \\ M. PREARO (2), M. C. ABETE (2)
}

(1) Dipartimento di Biologia Cellulare e Ambientale, Università degli Studi di Perugia, Via Pascoli, 06123 Perugia, Italy. * E-Mail: elia@unipg.it

(2) Istituto Zooprofilattico Sperimentale del Piemonte, Liguria eValle d'Aosta, Via Bologna, 148, 10154 Torino, Italy.

Reçu le 31 mai 2005

Accepté le 16 mars 2006

Received May 31, 2005

Accepted March 16, 2006

\begin{abstract}
Antioxidant parameters, such as total glutathione, glutathione S-transferase, glutathione peroxidase, glutathione reductase, glyoxalases, catalase, and some heavy metals such as, lead, cadmium and chromium were examined in hepatopancreas of both sexes of Procambarus clarkii collected seasonally from Lake Trasimeno, from winter 20002003 to autumn 2003. Heavy metals content in hepatopancreas in males and females of $P$. clarkii was low and did not vary through the sampling periods and between sexes. On the contrary, crayfish exhibited sex-dependent differences in levels of some enzyme activities and of total glutathione, and no apparent relationship was found between contaminant burdens and antioxidant indexes in hepatopancreas. Because measured metal concentrations were low, other factors, presumably, were involved in antioxidant variations in P. clarkii and these latter seemed to be affected more by biological and environmental factors, other than those related to pollutants body burdens.
\end{abstract}

Key-words: Procambarus clarkii, Lake Trasimeno, total glutathione, antioxidant enzymes, heavy metals.

\section{GLUTATHION ET ENZYMES ANTIOXYDANTS DANS L'HÉPATOPANCRÉAS DE L'ÉCREVISSE PROCAMBARUS CLARKII (GIRARD, 1852) DU LACTRASIMENO} (ITALIE)

\section{RÉSUMÉ}

Dans la présente étude les paramètres antioxydants comme le glutathion total, glutathion S-transférase, glutathion péroxidase, glutathion réductase, glyoxalase et catalase et les métaux lourds comme le plomb, cadmium et chrome ont été examinés dans l'hépatopancréas des mâles et femelles de $P$. clarkii. Les écrevisses ont été prélevées dans le Lac Trasimeno pendant toutes les saisons, de l'hiver 2002-2003 à l'automne 2003. Les niveaux d'accumulation des métaux lourds dans l'hépatopancréas des deux sexes de $P$. clarkii ont été bas et n'ont pas varié pendant la période de capture et entre les deux sexes. En revanche les écrevisses ont montré des différences dépendantes du sexe pour le niveau d'activité de quelques enzymes et le glutathion total. Aucune relation apparente 
n'a été trouvée entre l'accumulation des métaux lourds mesurés dans l'hépatopancréas et les indices antioxydants de l'hépatopancréas. Les concentrations des métaux basses et d'autres facteurs probablement sont impliqués dans les variations des indices antioxydants. Ces derniers semblent plus liés à l'habitat et aux facteurs biologiques qu'à la pollution.

Mots-clés: Procambarus clarkii, Lac Trasimeno, glutathion total, enzymes antioxydants, métaux lourds.

\section{INTRODUCTION}

In areobic cells, reactive oxygen species (ROS) such as superoxide anions $\left(\mathrm{O}_{2}^{-\bullet}\right)$, hydrogen peroxide $\left(\mathrm{H}_{2} \mathrm{O}_{2}\right)$ and hydroxyl radicals $\left(\mathrm{HO}^{*}\right)$ are generated during normal metabolism, particularly as a result of oxidative metabolism in mitochondrial membranes. Thus, to prevent oxidation-induced damage, caused by these reactive species, living organisms have evolved numerous defense mechanisms to counteract their harmful effects.

Reduced glutathione (GSH), the major non-protein thiol in animals, shows antioxidant properties. Under oxidative stress conditions, ROS are reduced by GSH, with the concomitant formation of the oxidized disulphide, GSSG. In addition, GSH acts as a cofactor in glutathione peroxidase mediated reduction of peroxides produced from $\mathrm{O}_{2} \bullet^{-}$. Glutathione reductase converts the GSSG to GSH by the expense of NADPH. Other defensive enzymes include glutathione S-transferase and glyoxalases. In fact, numerous xenobiotics containing reactive electrophilic centers conjugate with the thiol group of GSH either spontaneously or catalysed by glutathione S-transferases. Glyoxalase I acts upon the equilibrium adduct of methylglyoxal and GSH catalysing the formation of the thioester, S-D-lactoylglutathione, while glyoxalase II catalyses the hydrolysis of the thioester to regenerate GSH and liberate D-lactate. Another antioxidant enzyme, not glutathionedependent enzyme is catalase, which is involved in the cellular defense system through the elimination of hydrogen peroxide.

Abiotic factors can act as prooxidant forces rising ROS in aquatic organisms. A strategy to detect prooxidative xenobiotics is the employment of the level variations of antioxidant indicators (WINSTON and DI GIULIO 1991). However, the antioxidant defense mechanisms of aquatic organisms might show seasonal changes due to environmental and biological factors (LEMLYI, 1997; SHEEHNA and POWER, 1999). The range of physiological variability became necessary for a correct use of these biochemical parameters as indicators of environmental quality.

Procambarus clarkii, a native species of Northeastern Mexico and Southcentral United States (Lousiana), is a widespread species and was recorded for the first time in Lake Trasimeno (Central Italy) in 1999 (DÖRR et al., 2001). It survives in poor water quality, high and low temperatures, low oxygen concentrations and drying periods, reasons why it is able to occupy a wide variety of habitats (HUNER and LINQVIST, 1995). The results of field and laboratory studies have shown the sensitivity of the glutathione system in hepatopancreas of Procambarus clarkii (Girard, 1852) to different contaminants (NIES et al., 1991; BIRMELIN et al., 1998; FERNANDES et al., 2002).

No information is available for antioxidant parameters and environmental contaminant levels in Procambarus clarkii from Lake Trasimeno. This study was conducted seasonally in order to evaluate the differences in antioxidant response (total glutathione, glutathione Stransferase, glutathione reductase, glutathione peroxidase, glyoxalase I, glyoxalase II and catalase) in both sexes of Procambarus clarkii collected from Winter 2002-2003 to Autumn 2003 from Lake Trasimeno. In addition, some heavy metal concentrations (cadmium, 
chromium, and lead) in males and females of Procambarus clarkki were also investigated. The objective was to discriminate between biochemical variations linked to the biological cycle of the species and possible effects of these pollutants in crayfish.

\section{MATERIALS AND METHODS}

\section{Sampling site}

Lake Trasimeno has a tectonic origin and it is the largest lake of the Italian peninsula $\left(126 \mathrm{~km}^{2}\right)$. This laminar lake is characterized by an average depth of $4.7 \mathrm{~m}$ and a theoretical water return time of 24 years. Trasimeno is considered as pSIC (Sites of Community Importance) and ZPS (Special Protection Areas) according to BIOITALY (Italian ratification of the UE Directives HABITAT 92/43). Water temperature and lake levels were registered monthly from the hydrological station of the province of Perugia for the whole sampling period.

\section{Biochemical analysis}

A sample of 10 to 15 specimens of Procambarus clarkii of each sex was collected seasonally during the year 2002-2003 in winter (December and January), spring (March and April), summer (June and July), autumn (October and November) from Lake Trasimeno at the station of Panicarola by a professional fisherman, using 2 fyke nets at a depth of about $1.5 \mathrm{~m}$. All captured crayfish were transferred immediately live to the laboratory, where they were weighted and measured (mean total length $4.5 \pm 1.7 \mathrm{~cm}$; mean weight $21.60 \pm 7.90 \mathrm{~g}$ ) and the hepatopancreas was removed, rinsed with ice-cold saline, blotted dry and immediately stored at $-80^{\circ} \mathrm{C}$, until used.

The weighted tissues $(0.5 \mathrm{~g})$ were used for the determination of total glutathione, and for the enzymatic analyses as previously reported by ELIA et al. (2001). Total glutathione content (GSH+2GSSG) of hepatopancreas of both sexes was assayed by the GR recycling assay at $412 \mathrm{~nm}$ according to AKERBOOM and SIES (1981). Briefly, the assay was based on the enzymatic GSSG reductase assay in which the reaction mixture contained phoshate buffer, NADPH, dithionitrobenzoic acid, GSSG reductase. The reaction was monitored at $412 \mathrm{~nm}$, The amount of total glutathione was expressed as $\mathrm{nmol} / \mathrm{g}$ tissue.

Samples analyzed for enzyme activities $(0.5 \mathrm{~g})$ were homogenized in 10 volumes of 100 mMTRIS buffer, pH 7.8, containing $100 \mu \mathrm{M}$ phenylmethylsulphonyl fluoride (PMSF) and bacitracin $0.1 \mathrm{mg} \mathrm{ml}^{-1}$. Glutathione S-transferase activity (GST, EC 2.5.1.18), was measured according to HABIG et al. (1974) using the substrate 1-chloro-2,4-dinitrobenzene (CDNB). The assay of the activity with CDNB measured the formation of the conjugate with GSH at $340 \mathrm{~nm}\left(\varepsilon=9.6 \mathrm{mM}^{-1} \mathrm{~cm}^{-1}\right)$. Glutathione reductase activity (GR, EC 1.6.4.2) was assayed according to CHUNG et al. (1991) by following the oxidation of NADPH by glutathione reductase in presence of oxidixed glutathione at $340 \mathrm{~nm}\left(\varepsilon=-6.22 \mathrm{mM}^{-1} \mathrm{~cm}^{-1}\right)$. Glutathione peroxidase (GPx-selenium-dependent enzyme, EC 1.11.1.9) activity toward $\mathrm{H}_{2} \mathrm{O}_{2}$ as substrate was determined in a coupled enzyme system, where the GSSG formed in the GPx reaction was converted to the reduced form by glutathione reductase. The oxidation of NADPH was followed at $340 \mathrm{~nm}\left(\varepsilon=-6.22 \mathrm{mM}^{-1} \mathrm{~cm}^{-1}\right)$ (LAWRENCE and BURK, 1976). Catalase (EC 1.11.1.6) activity was measured according to GREENWALD (1985), following the decrease in absorbance at $240 \mathrm{~nm}$ due to $\mathrm{H}_{2} \mathrm{O}_{2}$ consumption $\left(\varepsilon=-0.04 \mathrm{mM}^{-1} \mathrm{~cm}^{-1}\right)$. Glyoxalase I (GI, EC 4.4.1.5) activity was determined according to ORAY and NORTON (1977) at $240 \mathrm{~nm}\left(\varepsilon=3.37 \mathrm{mM}^{-1} \mathrm{~cm}^{-1}\right)$ using $1.5 \mathrm{mM} \mathrm{GSH} /$ methylglyoxal hemithioacetal as substrate. Glyoxalase II (GII, EC 3.1.2.6) was determined according to PRINCIPATO et al. (1987) at $412 \mathrm{~nm}\left(\varepsilon=13.6 \mathrm{mM}^{-1} \mathrm{~cm}^{-1}\right)$ by monitoring GSH formation in the presence of 5,5'-dithio-bis-2-nitrobenzoic acid (DTNB) and S-D-lactoylglutathione (LSG). Protein concentration of supernatant fractions was determined according to LOWRY et al. (1951) employing bovine serum albumin (BSA) as a protein standard. 


\section{Chemical analysis}

Each sample of hepatopancreas of both sexes of crayfish was analyzed for determination of cadmium, chromium and lead. The sample tissue $(0.7-2 \mathrm{~g})$ was mineralized in microwave oven with a nitric acid and hydrogen peroxide mixture. The sample was filtered through filter paper into a $10 \mathrm{ml}$ volumetric flask followed by rinsing of both the flask and the filter paper with ultrapure water and made to volume with ultrapure water. The determinations of cadmium, chromium and lead were carried out by atomic absorption spectrophotometer with electrothermal atomization (GFAAS) Perkin-Elmer Aanalyst 600 (Norwalk - CT USA). The Zeeman effect was used to counteract aspecific absorption. Single element hollow - cathode lamps were used for lead $(\lambda=283.3 \mathrm{~nm})$, cadmium $(\lambda=228.8 \mathrm{~nm})$ and chromium $(\lambda=357.9)$. The calibration curves were made using standard solution (Standard Merck - Darmstadt Germany) of each metal. The quantification limit was $0.01 \mathrm{ppm}(\mu \mathrm{g} / \mathrm{g})$ for cadmium, $0.05 \mathrm{ppm}$ for chromium and $0.04 \mathrm{ppm}$ for lead (BALDINI et al., 1996).

\section{Statistical analysis}

Kruskal Wallis ANOVA test and the pairwise differences were tested using a Mann-Whitney $U$ test to discriminate differences for each sampling period and between sexes. Results are expressed as mean \pm SD of data. Biochemical data were conducted individually in 10 to 15 organisms of each sex per season and run by triplicate, while chemical analysis was conducted individually in 3 to 7 organisms of each sex per season. Significance was tested at the $5 \%$ level $(P<0.05)$.

\section{RESULTS}

In Figure 1 are reported the values of temperature and lake level recorded monthly from winter 2002-2003 to autumn 2003. As shown in this figure, the mean seasonal water temperature of Lake Trasimeno during the different sampling periods was $7.1 \pm 1.8^{\circ} \mathrm{C}$ in winter, $12.1 \pm 3^{\circ} \mathrm{C}$ in spring, $28.5^{\circ} \mathrm{C}$ in summer and $19 \pm 4.1^{\circ} \mathrm{C}$ in autumn. The mean seasonal water level of Lake Trasimeno during the same sampling periods was $-1.1 \pm 0.1 \mathrm{~m}$ in winter, $-1.1 \mathrm{~m}$ in spring, $-1.4 \pm 0.1 \mathrm{~m}$ in summer and $-1.8 \mathrm{~m}$ in autumn. The figure evidenced that the lowest lake level was reached in autumn (about minus 1.8 meter under the reference level, which is zero).

In Table I are reported the heavy metal concentrations in the hepatopancreas of Procambarus clarkii sampled seasonally from Lake Trasimeno. Statistical analysis did not reveal any significant differences for the sampling period and sexes, and thus only the observation of tendencies may be proposed. Among these, it is worth mentioning the higher levels of $\mathrm{Cd}$ in both sexes in autumn and of $\mathrm{Cr}$ in males in summer. This latter metal was at the lowest level (undetectable) in females during the warmest season. For $\mathrm{Pb}$ the highest level was displayed in males in autumn and in females in winter and summer.

Seasonal variations in biochemical parameters and differences between sexes were recognized in specimens of Procambarus clarkii sampled from this lake (Table II). Both sexes showed a marked difference in GST activity and it was higher in males than in females in spring (70\%), while in autumn the activity was $30 \%$ higher for females; in this latter season, all specimens displayed a marked induction (about 2-4 $\mathrm{x}$ ) of enzyme activity. A similar trend was observed for GR showing the highest activity in autumn, while the activity of females was about $100 \%$ higher than in males in spring and only slightly higher in autumn. Se-GPx activity was at the highest level in summer (about $2.5 \mathrm{x}$ ) and no differences between sexes were recorded in this study. Males displayed the lowest CAT activity during all seasons, except in summer and marked differences between sexes were recorded from winter to summer and it was about 2.5 times higher in females than in 


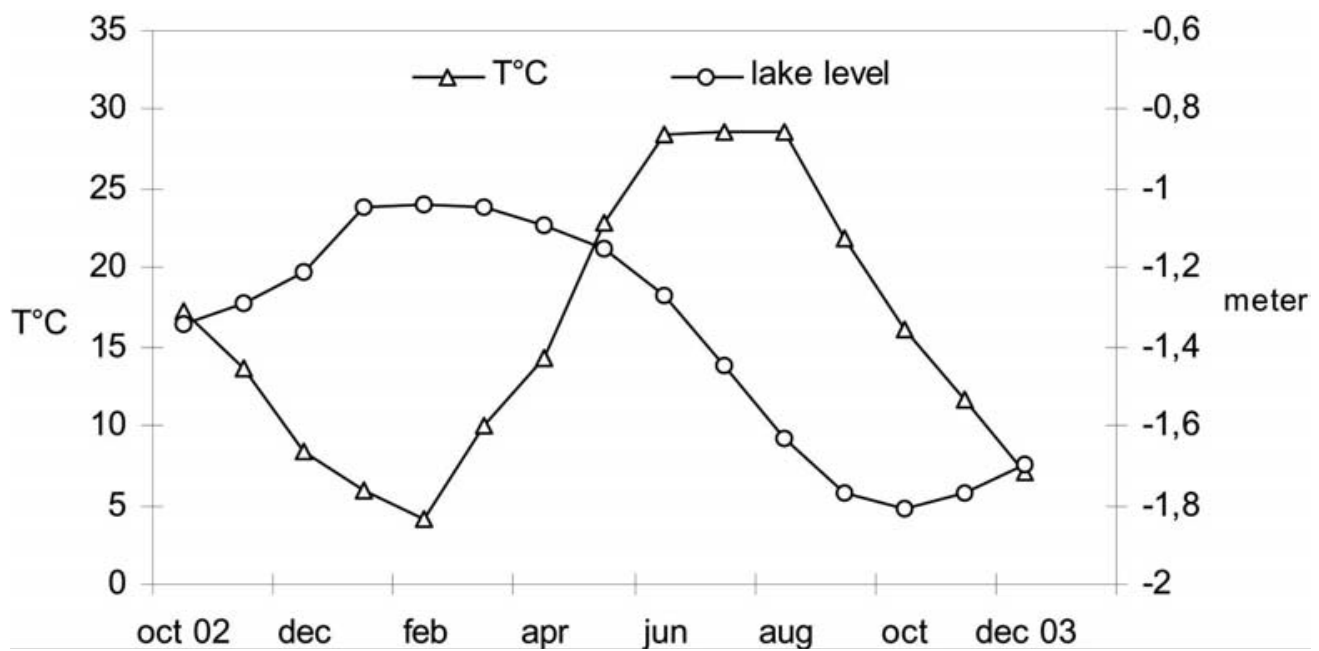

\section{Figure 1}

Water level and temperature of Lake Trasimeno. Levels are indicated in meters under the reference level, which is zero. The temperature is reported monthly in ${ }^{\circ} \mathbf{C}$.

\section{Figure 1}

Niveau et température du LacTrasimeno. Les niveaux sont indiqués en mètres sous le niveau de référence qui est zéro. La température est reportée mensuellement en ${ }^{\circ} \mathbf{C}$.

males. The highest activity of Gl was displayed by males in all seasons except in autumn, and by females during the warmer seasons. The enzyme activity was higher in females than in males in spring and summer, while the opposite trend was displayed during the colder seasons. Gll activity was higher in autumn (about $3 x$ ) and the activity was greater for males in winter and autumn (about 30-50\%, respectively). The only difference recognized for total glutathione level between sexes was in winter and autumn, which was about 30\% lower in females than in males; in autumn a decreased thiol level was recorded mainly for males.

Biochemical and chemical parameters in hepatopancreas of females and males were examined with the non parametric Spearman's rank correlations and no statistically significant correlation was found (data not shown).

\section{DISCUSSION}

It was reported in some field studies that Procambarus clarkii can be employed as an accumulative indicator of heavy metals giving information about the pollutants contamination in different sites (ROWE et al., 2001; SANCHEZ LOPEZ et al., 2004).

The only information previously reported by us, about heavy metal accumulation in aquatic species from Trasimeno is referred to metal accumulation in fish species (GALARINI et al., 2002; ELIA et al., 2005). Our data indicated that heavy metal contents in muscle, and other organic contaminants, such as PCB in fish from Trasimeno were low, if compared to other Umbrian lakes (GALARINI et al., 2002; ELIA et al., 2005).- 


\section{Table I}

Levels $(\mu \mathrm{g} / \mathrm{g})$ of Cadmiun, Chromium and Lead in hepatopancreas of Procambarus clarkii.

Tableau I

Concentrations $(\mu \mathrm{g} / \mathrm{g})$ de cadmium, chrome et plomb dans l'hépatopancréas de Procambarus clarkii.

\begin{tabular}{|c|c|c|c|c|c|}
\hline Metals & Sex & $\begin{array}{c}\text { Winter } \\
2002-2003 \\
(\delta=3 ;+=4)\end{array}$ & $\begin{array}{c}\text { Spring } \\
2003 \\
(\text { ๙ }=4 ; \uparrow=4)\end{array}$ & $\begin{array}{c}\text { Summer } \\
2003 \\
(\delta=4 ; q=4)\end{array}$ & 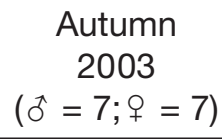 \\
\hline \multirow{2}{*}{$\mathrm{Cd}$} & o & $\begin{array}{c}0.072 \pm 0.080 \\
{[0.01-0.19]}\end{array}$ & $\begin{array}{c}0.030 \pm 0.008 \\
{[0.02-0.04]}\end{array}$ & $\begin{array}{c}0.015 \pm 0.017 \\
{[\text { nd- } 0.04]}\end{array}$ & $\begin{array}{c}0.109 \pm 0.213 \\
\text { [nd-0.59] }\end{array}$ \\
\hline & q & $\begin{array}{c}0.018 \pm 0.019 \\
{[\text { n.d-0.04] }}\end{array}$ & $\begin{array}{c}0.060 \pm 0.068 \\
{[0.01-0.16]}\end{array}$ & $\begin{array}{c}0.008 \pm 0.007 \\
{[n d-0.02]}\end{array}$ & $\begin{array}{c}0.070 \pm 0.102 \\
{[0.01-0.29]}\end{array}$ \\
\hline \multirow[b]{2}{*}{$\mathrm{Cr}$} & o & nd & nd & $0.076 \pm 0.102$ & nd \\
\hline & 우 & $\begin{array}{c}0.033 \pm 0.014 \\
{[\text { nd- } 0.05]}\end{array}$ & $\begin{array}{c}0.033 \pm 0.017 \\
{[\text { nd }-0.06]}\end{array}$ & $\begin{array}{c}\text { [nd-0.23] } \\
\text { nd }\end{array}$ & $\begin{array}{c}0.028 \pm 0.009 \\
{[\text { nd }-0.05]}\end{array}$ \\
\hline \multirow{2}{*}{$\mathrm{Pb}$} & $0^{0}$ & $\begin{array}{c}0.087 \pm 0.041 \\
{[0.05-0.14]}\end{array}$ & $\begin{array}{c}0.085 \pm 0.050 \\
{[0.02-0.14]}\end{array}$ & $\begin{array}{c}0.045 \pm 0.025 \\
{[0.02-0.08]}\end{array}$ & $\begin{array}{c}0.197 \pm 0.183 \\
{[0.04-0.51]}\end{array}$ \\
\hline & q & $\begin{array}{c}0.153 \pm 0.140 \\
{[0.04-0.31]}\end{array}$ & $\begin{array}{c}0.082 \pm 0.065 \\
{[0.02-0.17]}\end{array}$ & $\begin{array}{c}0.117 \pm 0.065 \\
{[0.06-0.21]}\end{array}$ & $\begin{array}{c}0.080 \pm 0.058 \\
{[0.02-0.20]}\end{array}$ \\
\hline
\end{tabular}

Value ranges are indicated in brackets; $\mathrm{nd}=$ not detectable.

L'écart des valeurs est indiqué entre crochets; nd = non déterminé

In the present study, metal level determination was performed only on the hepatopancreas which was also the tissue employed for the biochemical analysis. The hepatopancreas was chosen for both analyses, because this tissue shows elevated concentrations of these biochemical indicators in aquatic organisms, and therefore can better reflect the biochemical variations linked to the biological cycle or to the effects of pollutants. Heavy metals content in hepatopancreas of females and males of Procambarus clarkii collected seasonally from Trasimeno, was low, almost constant through the sampling period and did not show any difference between sexes as indicated in Table 1. European legislation recently fixed the limits for Cd and $\mathrm{Pb}$ in crustacea products (EC Council Regulation 221/2002). According to this Regulation the crayfish collected seasonally did not show $\mathrm{Pb}$ and $\mathrm{Cd}$ concentrations in hepatopancreas exceeding the limit of $0.5 \mathrm{mg} / \mathrm{kg}$ wet weight, except for one male collected in autumn. Consequently, the values of these pollutants in hepatopancreas of Procambarus clarkii from Trasimeno indicate that this lake has a low contamination risk from these contaminants. However, to access the contamination risk via the Cd limits, accumulation level should be also measured in other tissues as gills and carapace, which might accumulate high levels of pollutants. More studies will be carried out in our laboratory to investigate this aspect. 


\section{Table II}

Enzymatic activities and total glutathione in Procambarus clarkii from Lake Trasimeno sampled from winter 2000-2003 to autumn 2003.

Tableau II

Activités enzymatiques et glutathion total de Procambarus clarkii dans le Lac Trasimeno prélevées de l'hiver 2002-2003 à l'automne 2003.

\begin{tabular}{|c|c|c|c|}
\hline & Seasons & Males (ð) & Females (q) \\
\hline GST & $\begin{array}{l}\text { Winter } \\
\text { Spring } \\
\text { Summer } \\
\text { Autumn* }\end{array}$ & $\begin{array}{l}183.66 \pm 60.47^{c} \\
281.23 \pm 64.51^{b} \\
231.50 \pm 92.07^{b c} \\
464.57 \pm 98.83^{a}\end{array}$ & $\begin{array}{l}144.36 \pm 44.26 \mathrm{~b} \\
161.82 \pm 28.42^{b} \\
156.89 \pm 45.97^{b} \\
600.26 \pm 140.44^{a}\end{array}$ \\
\hline GR & $\begin{array}{l}\text { Winter } \\
\text { Spring* } \\
\text { Summer } \\
\text { Autumn* }\end{array}$ & $\begin{array}{l}7.07 \pm 1.66^{d} \\
10.52 \pm 3.14^{c} \\
15.34 \pm 5.03^{b} \\
38.01 \pm 6.43^{a}\end{array}$ & $\begin{array}{l}11.24 \pm 4.0^{c} \\
20.06 \pm 7.22^{b} \\
17.72 \pm 4.83^{b c} \\
48.50 \pm 7.74^{a}\end{array}$ \\
\hline Se-GPx & $\begin{array}{l}\text { Winter } \\
\text { Spring } \\
\text { Summer } \\
\text { Autumn }\end{array}$ & $\begin{array}{l}63.13 \pm 14.29^{c} \\
101.77 \pm 25.44^{b} \\
169.45 \pm 47.72^{a} \\
59.25 \pm 11.68^{c}\end{array}$ & $\begin{array}{l}61.80 \pm 19.02^{b} \\
131.41 \pm 34.29^{a} \\
181.47 \pm 64.33^{a} \\
70.27 \pm 9.85^{b}\end{array}$ \\
\hline CAT & $\begin{array}{l}\text { Winter }^{\star} \\
\text { Spring* } \\
\text { Summer* } \\
\text { Autumn }\end{array}$ & $\begin{array}{l}7.93 \pm 1.57^{b} \\
7.70 \pm 2.65^{b} \\
15.48 \pm 3.02^{a} \\
8.84 \pm 1.17^{b}\end{array}$ & $\begin{array}{l}18.07 \pm 9.47^{b} \\
19.76 \pm 6.25^{b} \\
29.91 \pm 7.34^{a} \\
10.29 \pm 1.83^{c}\end{array}$ \\
\hline Gl & $\begin{array}{l}\text { Winter }^{*} \\
\text { Spring* } \\
\text { Summer }^{*} \\
\text { Autumn* }\end{array}$ & $\begin{array}{l}251.47 \pm 91.68^{a} \\
265.76 \pm 72.61^{a} \\
297.06 \pm 68.89^{a} \\
136.78 \pm 27.66^{b}\end{array}$ & $\begin{array}{l}111.07 \pm 10.92^{c} \\
375.30 \pm 85.79^{b} \\
445.02 \pm 36.86^{a} \\
59.95 \pm 19.90^{d}\end{array}$ \\
\hline Gll & $\begin{array}{l}\text { Winter* } \\
\text { Spring } \\
\text { Summer } \\
\text { Autumn* }\end{array}$ & $\begin{array}{l}73.38 \pm 15.79^{c} \\
71.95 \pm 12.32^{c} \\
116.63 \pm 22.35^{b} \\
231.63 \pm 65.94^{a}\end{array}$ & $\begin{array}{l}55.17 \pm 10.48^{c} \\
72.17 \pm 15.31^{b} \\
115.77 \pm 34.49^{a} \\
154.94 \pm 38.91^{a}\end{array}$ \\
\hline $\mathrm{GSH}+2 \mathrm{GSSG}$ & $\begin{array}{l}\text { Winter* } \\
\text { Spring } \\
\text { Summer } \\
\text { Autumn* }\end{array}$ & $\begin{array}{l}508.92 \pm 133.31^{a} \\
408.38 \pm 96.59^{a} \\
504.92 \pm 125.20^{a} \\
345.26 \pm 86.86^{b}\end{array}$ & $\begin{array}{l}324.11 \pm 81.99^{b c} \\
409.31 \pm 74.57^{b} \\
519.31 \pm 59.85^{a} \\
257.71 \pm 88.86^{c}\end{array}$ \\
\hline
\end{tabular}

Mean values \pm SD $(n=10,11,12,15$ males; $n=10,10,11,13$ females for each sampling time, respectively). Statistical comparison: different letters $(a, b, c)$ indicate significant differences between sampling seasons in the same colomn; asterisk $\left(^{*}\right)$ indicates significant differences between females and males in the same line $(P<0.05)$. GST, Se-GPX, GR are reported in $\mathrm{nmol} / \mathrm{min} / \mathrm{mg}$ protein, CAT in $\mu \mathrm{mol} / \mathrm{min} / \mathrm{mg}$ protein and $\mathrm{GSH}+2 \mathrm{GSSG}$ in $\mathrm{nmol} / \mathrm{g}$ wet weight.

Valeurs moyennes $\pm \mathrm{DS}(\mathrm{n}=10,11,12,15$ mâles $; n=10,10,11,13$ femelles pour chaque période de récolte, respectivement). Comparaison statistique: différentes lettres ( $a, b, c)$ dans la même colonne indiquent les différences significatives entre les saisons de récolte ; l'astérisque $\left.{ }^{*}\right)$ indique les différences significatives entre femelles et mâles sur la même ligne $(P<0,05)$. GST, Se-GPX, GR sont reportés in $\mathrm{nmol} / \mathrm{min} / \mathrm{mg}$ protéine, CAT en $\mu \mathrm{mol} / \mathrm{min} / \mathrm{mg}$ protéine et $\mathrm{GSH}+2 \mathrm{GSSG}$ en $\mathrm{nmol} / \mathrm{g}$ poids humide. 
As observed in this investigation, both sexes of Procambarus clarkii collected from Trasimeno, showed significant differences of biochemical parameters according to sexes and seasons and thus, these changes appear to be linked more to biological status and environmental factors, than to the presence of heavy metals in hepatopancreas. In fact, GST activity evaluated seasonally in both sexes was higher in males, except for autumn, than in females. This result may be due to the different regulation of GST expression between sexes during the reproductive cycle and as evidenced in this study, almost all females sampled in autumn had mature ovarian eggs of brown color. In fact, the reproductive period for this crayfish species in Lake Trasimeno is autumn and seems to be linked to temperature and lake level. The results of a field study performed on Procambarus clarkii collected from Lake Trasimeno during the year 2000-2001 showed that ovarian eggs started maturation at water temperature over $20^{\circ} \mathrm{C}$ and when the lake level started to decrease (DÖRR, personal comunication). In addition, GST activity in autumn was almost two to four times higher in both sexes, than the activity recorded in other seasons. The marked induction of GST activity could reflect an oxidative stress condition in these specimens which may be caused by the lowest lake level recorded for Trasimeno in October-November. In fact, this lake is regularly subjected to significant hydrologic fluctations and mainly during the sampling year (20022003) it reached the minimum level in October-November. Little information is available on detoxifying enzymes and also on the influence of seasonal changes on these biochemical indicators on freshwater crayfish species like Procambarus clarkii. It was reported that GST activity measured in hepatopancreas of Procambarus clarkii collected monthly for a whole year of 1988, showed a seasonal variation and the activity was correlated with the pesticide fenitrothion present in Lake Albufera (Spain) (NIES et al., 1991). Moreover, the results of a laboratory study indicated that GST activity in this species increased after the exposure to the organophosphate insecticide fenitrothion at $5 \mu \mathrm{M}$ concentration (BIRMELIN et al., 1998), whereas GST activity togheter with glutathione content were depleted in the midgut of $P$. clarkii by cadmium exposure (ALMAR et al., 1987).

In the present research, the examination of the seasonal biochemical progress in crayfish from Trasimeno reveals that the increase of GST activity in examined tissue, mainly in autumn, was concomitant with the rise of GR and Gll activities. GR enzyme has the ability to regenerate the GSH from GSSG and the induction of its activity is employed as biomarker of oxidative stress in living organisms (STAGEMAN et al., 1992). In this study, increased GR activity might indicate an enhancement in total glutathione consumption used as a defense against prooxidative processes which happen in these specimens during autumn, when the lake is at the lowest level and when reproduction of Procambarus clarkii in Trasimeno starts.

The marked induction of Se-GPx and CAT enzymatic activities in P. clarkii of Trasimeno, mainly in summer, might be due to an increased metabolic activity of the organism compared to the other seasons. The metabolic status can influence the defense capacity of organisms against environmental parameters changes and/or xenobiotics (SHEEHAN and POWER, 1999). An increase in antioxidant enzymes activities could be related to reproductive events in invertebrate organisms (VIDAL et al., 2002) or to the higher metabolic activity of the organisms during the warmer season (REGOLI, 1998). In this study, CAT activity was always higher in females than males in almost all seasons, except in autumn, when the activity was equal for both sexes. Probably the significant reduction in CAT activity, in females during autumn could be correlated with the spawning period of this species. Thus, the seasonal variations of CAT and Se-GPX activities recorded in both sexes of Procambarus clarkii in our current study, indicated a greater prooxidant challenge during the warmer seasons.

Gl and Gll enzymes are employed as biomarkers of oxidative stress in freshwater organisms in field (ELIA et al., 2006) and laboratory studies (ELIA et al., 2003). This enzymatic system was also subjected to seasonal variation in vertebrate (ELIA 
et al., 2005) and invertebrate organism (ELIA et al., 2001). In the current research are reported the first results of glyoxalases system (GI and GII) of Procambarus clarkii. Females and males showed a significant difference in Gl activity during all seasons, probably related to the modification of hormonal status. The higher Gl level during spring and summer might be interpreted as the outcome of the higher metabolic activity of the species in these seasons which are characterized by moult for both sexes before the spawning period occurs. On the contrary, the greater Gll activity in both sexes in autumn seems to be a response to prooxidative factors may be due to reproduction which is directly linked to the lowest lake level and decreasing water temperature (DÖRR, personal comunication).

Only few data about the thiol content in this crayfish species and the differences linked to sexes are reported in literature (ALMAR et al., 1987). Particularly, these authors evidenced a very slight differences in GSH and GST levels between sexes. On the contrary, in this current study, females exhibited lower glutathione levels than did males, mainly during the colder seasons, probably as a result of different metabolic and hormonal status during internal egg maturation. Futhermore, the depleted content in autumn of both sexes may be due to prooxidative processes which could happen during this season, when the lake was at the lowest level, water temperature decreased rapidly and reproduction occured. Generally, the decreased thiol levels in organisms reflect a weakened defense ability which may facilitate the onset of oxidative damage and an prooxidant status.

\section{CONCLUSION}

A general result of this study is that the biochemical indexes investigated in specimens of both sexes of Procambarus clarkii sampled from Lake Trasimeno were not related to any heavy metal analyzed in hepatopancreas. The low metal accumulation indicates that the observed biochemical variations are most likely due to the changes in biological and environmental factors such as reproduction, water temperature and lake level. However, using this species for spatial and temporal comparision in order to assess environmental quality, caution should be taken in employing Procambarus clarkii in biomonitoring programs, above all in considering biochemical variations recorded between sexes. These biochemical changes may provide important background information for the implementation of biomarker-based monitoring programs using this crayfish species.

\section{AKNOWLEDGEMENTS}

This study was financially supported by the Province of Perugia, 2002 (Italy).

\section{REFERENCES}

ALMAR M.M., DIAZ-MAYANS J., ROMERO F.J., 1987. Glutathione content and glutathione S-transferase activity in midgut gland of Procambarus clarkii. Sex differences, the effect of fasting, and their implications in cadmium toxicity. Comparative Biochemistry and Physiology C, 87, 433-435.

AKERBOOM T.P.M., SIES H., 1981. Assay of glutathione disulfide and glutathione mixed disulfide in biological samples. Methods in Enzymology, 71, 373-382.

BALDINI M., FABIETTI F., GIANMARIOLI S., ONORI R., OREFICE L., STACCHINI A., 1996. Metodi di analisi utilizzati per il controllo chimico degli alimenti. Rapporti ISTISAN 96/34.

BIRMELIN C., ESCARTIN E., GOLDFARB P.S., LIVINGSTONE D.R., PORTE C., 1998. Enzyme effect and metabolism of fenitrothion in primary cell culture of the red swamp crayfish Procambarus clarkii. Marine Environmental Research, 46, 375-378. 
CHUNG P.M., CAPPEL R.E., GILBERT H.F., 1991. Inhibition of glutathione disulfide reductase by glutathione. Archives Biochemistry and Biophysics, 288, 48-53.

DÖRR A.J.M., PEDICILLO G., LORENZONI M., 2001. Prima segnalazione di Procambarus clarkii, Orconectes limosus e Astacus leptodactylus (Crustacea Decapoda) in Umbria. Rivista di Idrobiologia, 40, 221-233.

EC Council Regulation 221/2002.

ELIA A.C., LUDOVISI A., TATICCHI M.I., 2001. Study of seasonal variations of glutathione and detoxificant enzymes in Lophopus crystallinus Pallas (Bryozoa) from Piediluco lake (Umbria, Italy). Italian Journal of Zoology, 68, 291-297.

ELIA A.C., GALARINI R., TATICCHI M.I., DÖRR A.J.M., MANTILACCI L., 2003. Antioxidant responses and bioaccumulation in Ictalurus melas under mercury exposure. Ecotoxicology Environmental Safety, 55, 162-167.

ELIA A.C., GALARINI R., DÖRR A.J.M., TATICCHI M.I., 2006. Bioaccumulation of heavy metals, organochlorine pesticides and detoxificant biochemical indexes in tissues of Ictalurus melas of Lake Trasimeno. Bullettin Environmental Contamination and Toxicology, 76: 132-139.

ELIA A.C., GALARINI R., DÖRR A.J.M., CARNEVALI O., FIORONI L., TATICCHI M.I., 2005. Polychlorinated biphenyls and antioxidant enzymes in liver of Cyprinus carpio L. from Lake Trasimeno. Italian Journal of Zoology, 72, 1-7.

FERNANDES D., POTRYKUS J., MORSIANI C., RALDUA D., LAVADO R., PORTE C., 2002. The combined use of chemical and biochemical markers to asses water quality in two low-stream rivers. Environmental Research, 90, 169-178.

GALARINI R., HAOUET M.N., ELIA A.C., 2002. Heavy Metals, HCB and p,p'-DDE in Ictalurus melas Raf. from Trasimeno and Corbara Lakes (Italy). Bullettin of Environomental Contamination and Toxicology, 68, 230-236.

GREENWALD R.A., 1985. Handbook of Methods for Oxygen Radical research. CRC Press, Boca Raton, FL, 276.

HABIG W.H., PABST M.J., JAKOBY W.B., 1974. Glutathione S trasferases. The first enzymatic step in mercapturic acid formation. Journal of Biological Chemistry, 249, 7130-7139.

HUNER J.V., LINDQVIST O.V., 1995. Physiological adaptations of freshwater crayfishes that permit successful aquaculture enterprises. American Zoologist, 35, 12-19.

LAWRENCE R.A., BURK R.F., 1976. Glutathione peroxidase activity in selenium-deficient rat liver. Biochemical Biophysical Research Communications, 71, 592-598.

LEMLYI A.D., 1997. Role of season in aquatic hazard assessment. Environmental Monitoring and Assessment, 45, 89-98.

LOWRY O.H., ROSEBROUGH N.J., FARR A.L., RANDALL R.J., 1951. Protein measurement with the Folin phenol reagent. Journal of Biological Chemistry, 193, 265-275.

NIES E., ALMAR M.M., HERMENEGILDO C., MONSALVE E., ROMERO F.J., 1991. The activity of glutathione S-transferase in hepatopancreas of Procambarus clarkii: seasonal variations and the influence of environmental pollutants. Comparative Biochemistry and Physiology C, 100, 65-66.

ORAY B., NORTON S.J., 1977. Two step purification of mouse liver glyoxalase I and evidence of its dimeric constitution. Biochimica et Biophysica Acta, 483, 203-208.

PRINCIPATO G.B., ROSI G., TALESA V., GIOVANNINI E., UOTILA C., 1987. Purification and characterization of two forms of Gll from the liver and brain of Winstar rats. Biochimica et Biophysica Acta, 911, 349-355. 
REGOLI F., 1998. Trace metals and antioxidant enzymes in gills and digestive gland of the Mediterranean mussel Mytilus galloprovincialis. Archives of Environmental Contamination and Toxicology, 34, 48-63.

ROWE C.L., HOPKINS W.A., ZEHNDER C., CONGDON J.D., 2001. Metabolic costs incurred by crayfish (Procambarus clarkii) in a trace element-polluted habitat: further evidence of similar responses among diverse taxonomic groups. Comparative Biochemistry and Physiology C, 129, 275-283.

SANCHEZ LOPEZ F.J., GIL GARCIA M.D., MARTINEZ VIDAL J.L., AGUILERA P.A., GARRIDO FRENICH A., 2004. Assessment of metal contamination in Donana National Park (Spain) using crayfish (Procamburus clarkii). Environmental Monitoring Assessment, 93, 17-29.

SHEEHAN D., POWER A., 1999. Effects of seasonality on xenobiotic and antioxidant defence mechanisms of bivalve molluscs. Comparative Biochemistry and Physiology C, 123, 193-199.

STAGEMAN J.J., BROUWER M., DI GIULIO R.T., FÖRLIN L., FOWLER B.A., SANDERS B.M,, VAN VELD P.A., 1992. Molecular responses to environmental contamination: enzyme and protein systems as indicators of chemical exposure and effect. In: R.J. HUGGETT, R.A. KIMERLE, P.M. MEHRLE and H.L. BERGMAN (Eds), Biomarkers: Biochemical, Physiological and Hystological markers of Anthropogenic stress. Lewis, Boca Raton, FL, 235-335.

VIDAL M.L., BASSERES A., NARBONNE J.F., 2002. Seasonal variation of pollution biomarkers in two population of Corbicula fluminea (Müller). Comparative Biochemistry and Physiology C, 131, 133-151.

WINSTON G.W., DI GIULIO R.T., 1991. Prooxidant and antioxidant mechanisms in aquatic organisms. Aquatic Toxicology, 137-161. 
